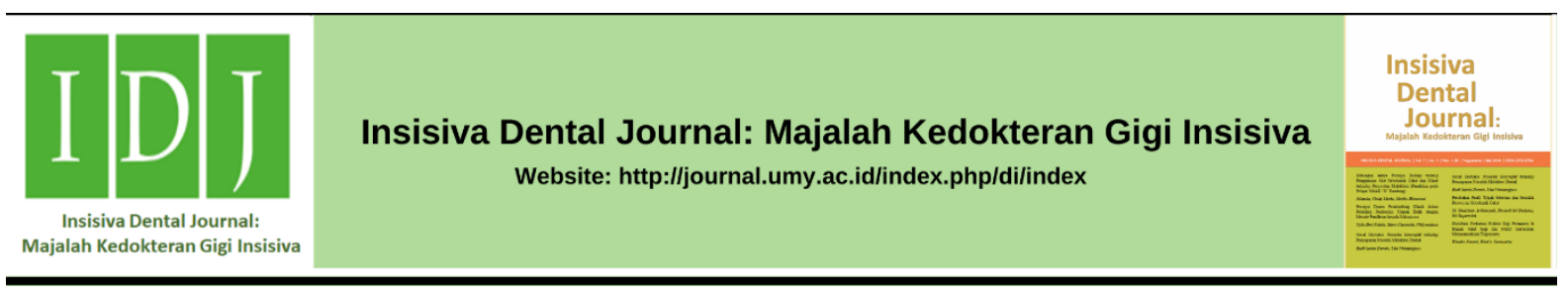

Research Article

\title{
Daya Antibakteri Ekstrak Jintan Hitam dan Daun Sirih terhadap Staphylococcus aureus pada Plat Gigi Tiruan
}

Antibacterial Power of Black Seed and Betel Leaf Extract towards Staphylococcus aureus on Denture Base

\author{
Zeny Putri Ayu ${ }^{1}$, Hastoro Pintadi ${ }^{2}$ * \\ ${ }^{1}$ Program Studi Kedokteran Gigi, Fakultas Kedokteran dan Ilmu Kesehatan, Universitas Muhammadiyah Yogyakarta, Jalan Brawijaya, \\ Tamantirto, Kasihan, Bantul, Indonesia. \\ ${ }^{2}$ Bagian Ilmu Kesehatan Gigi Masyarakat, Program Studi Kedokteran Gigi, Fakultas Kedokteran dan Ilmu Kesehatan, Universitas \\ Muhammadiyah Yogyakarta, Jalan Brawijaya, Tamantirto, Kasihan, Bantul, Indonesia.
}

Received date: November $19^{\text {th }}, 2019$; reviewed date: December $27^{\text {th }}, 2019$ revised date: January $5^{\text {th }}, 2020$; accepted date: March $31^{\text {st }}, 2020$ DOI : 10.18196/di.9113

\begin{abstract}
Abstrak
Resin akrilik heat-cure sebagai bahan membuat plat gigi tiruan memiliki kekurangan yaitu porositas permukaan yang kasar pada bagian fitting surface, sehingga akumulasi sisa makanan dan mikroorganisme seperti Staphylococcus aureus dapat berkembang dan menimbulkan denture stomatitis. Pencegahan dapat dilakukan dengan merendam gigi tiruan pada larutan yang mengandung antibakteri seperti jintan hitam dan daun sirih yang mengandung thymoquinon, thymohydroquinone, tannin, kavikol, fenol, seskuiterpan, dan flavanoid. Penelitian ini bertujuan untuk mengetahui perbedaan daya antibakteri ekstrak jintan hitam dan daun sirih hijau terhadap Staphylococcus auerus pada plat gigi tiruan. Penelitian ini merupakan penelitian eksperimental laboratoris. Sampel penelitian berupa 27 plat resin akrilik yang selanjutnya dibagi menjadi 3 kelompok berdasarkan jenis larutan perendamannya yaitu dengan larutan ekstrak jintan hitam $0,5 \%$, larutan daun sirih $25 \%$, dan aquades sebagai kontrol negatif. Data dianalisis menggunakan Mann-Whitney test. Hasil rata-rata pertumbuhan bakteri pada larutan jintan hitam $0,5 \%$ yaitu 3,11; larutan daun sirih 25\% yaitu 1.00; aquades yaitu 6.00. Hasil uji MannWhitney Test menunjukkan $\mathrm{p}=0,135(\mathrm{p}>0,05)$ yang berarti tidak ada perbedaan bermakna antara kelompok perlakuan. Dapat disimpulkan bahwa ekstrak jintan hitam dan ekstrak daun sirih tidak memiliki perbedaan bermakna dalam menghambat pertumbuhan bakteri Staphylococcus aureus.
\end{abstract}

Kata Kunci: Daun Sirih (Piper betle L); Jintan Hitam (Nigella sativa); Resin Akrilik; Staphylococcus aureus

\begin{abstract}
Heat-cure acrylic resin as a material to create denture plates has the disadvantage of rough surface porosity in the fitting surface so that the accumulation of food scraps and microorganisms such as Staphylococcus aureus can develop and cause denture stomatitis. Prevention can be carried out by soaking the denture in an antibacterial solution, such as black cumin and betel leaf containing thymoquinone, thymohydroquinone, tannin, chavicol, phenol, sesquiterpene, and flavanoid. This study aims to determine differences in the antibacterial power of black cumin extract and green betel leaf against Staphylococcus aureus on denture plates. This research is experimental laboratory research. The research sample consisted of 27 acrylic resin plates, which were further divided into three groups based on the type of immersion solution, namely $0.5 \%$ of black cumin extract solution, $25 \%$ of betel leaf solution, and distilled water as a negative control. Data were analyzed using the Mann-Whitney test. The average yield of bacterial growth in $0.5 \%$ of black cumin solution was 3.11; $25 \%$ of betel leaf solution was 1.00 ; distilled water was 6.00. A Mann-Whitney test result showed $p=0.135$ ( $p>0.05)$, which indicated there was no significant difference among the treatment groups. It can be concluded that black cumin extract and betel leaf extract have no significant differences in inhibiting the growth of Staphylococcus aureus bacteria.
\end{abstract}

Keywords : Betel leaf (Piper betle L); Black cumin (Nigella sativa); Acrylic resin; Staphylococcus aureus

\footnotetext{
* Corresponding author, e-mail: phastoro@ymail.com
} 


\section{PENDAHULUAN}

Gigi tiruan merupakan protesa yang digunakan untuk menggantikan gigi yang hilang. Masyarakat Indonesia yang menggunakan gigi tiruan mencapai 4,5\% dan di Yogyakarta penggunaan gigi tiruan mencapai 5,9\%. ${ }^{1}$ Bahan yang sering digunakan oleh dokter gigi dalam pembuatan plat gigi tiruan adalah resin akrilik. Pemilihan penggunaan resin akrilik sebagai bahan gigi tiruan karena estetiknya baik, harga murah, mudah dimanipulasi, tidak larut dalam cairan mulut, mudah direparasi, dan mudah dibersihkan. ${ }^{2}$ Sedangkan kekurangan dari resin akrilik adanya porositas pada permukaan sehingga permukaan menjadi kasar. Hal ini terjadi pada tahap pengadukan yang tidak tepat antara bubuk dan cairan. ${ }^{3}$

Porositas pada permukaan plat gigi tiruan yang kasar akan memudahkan terjadinya akumulasi dari sisa-sisa makanan dan mikoroogansime. Deposit plak dan sisa makanan tersebut dapat menyebabkan mikroorganisme yang terdapat pada membran mukosa rongga mulut bereaksi. ${ }^{4}$ Mikroorganisme flora normal manusia yang sering ditemukan pada rongga mulut salah satunya adalah Staphylaccocus aureus. Menurut penelitian yang sudah dilakukan Monroy (2005), ${ }^{5}$ orang yang menggunakan gigi tiruan yang mengalami denture stomatitis pada membran mukosanya terdapat Candida albican 66,7\%, Staphylococcus aureus dan Streptococcus mutans sebanyak 49,5\%.

Bagian plat akrilik yang berkontak langsung dengan saliva akan mengabsrobsi molekul saliva, dan membentuk lapisan tipis yang disebut acquired pellicle. Protein yang terkandung dalam pellicel dapat mengikat mikroorganisme rongga mulut, sehingga mikroorganisme yang melekat pada permukaan gigi tiruan akan berkembang biak dan berkoloni dengan mikroorganisme lainnya untuk membentuk plak gigi tiruan. Plak tersebut akan menyebabkan gangguan pada pengguna gigi tiruan salah satu dampaknya adalah peradangan pada jaringan mukosa dibawah gigi tiruan yang disebut denture stomatitis. ${ }^{6}$

Denture Stomatitis merupakan gangguan umum bagi pengguna gigi tiruan. Hal ini ditandai sebagai peradangan dan eritema pada area mukosa mulut yang ditutupi oleh gigi tiruan. Faktor lain yang menyebabkan denture stomatitis yaitu usia pengguna gigi tiruan, penggunaan gigi tiruan terus menurus dan kurangnya menjaga kerbersihan rongga mulut pengguna gigi tiruan. ${ }^{7}$

Menjaga kebersihan gigi tiruan dapat mengurangi akumulasi sisa-sisa makanan dan plak serta perlekatan bakteri pada permukaan gigi tiruan untuk mencegah terjadinya denture stomatitis. Perawatan kebersihan gigi tiruan dapat dilakukan dengan cara mekanik, membersihkan gigi tiruan menggunakan sikat, pasta atau bubuk, dan pembersih ultrasonik. ${ }^{8}$ Pembersihan dengan kimiawi biasanya dilakukan dengan cara perendaman gigi tiruan dengan menggunakan larutan desinfektan, alkali peroksida, alkali hipoklorit, dan enzim. ${ }^{9}$

Daun sirih (Piper betle L.) merupakan tanaman yang sudah lama dipakai orang Indonesia dan bangsa-bangsa Asia lainnya yang telah terbukti secara ilmiah memiliki aktivitas sebagai antibakteri (daya antiseptik), antioksidan, dan antijamur. ${ }^{10}$ Kandungan daun sirih yang dapat menghambat pertumbuhan bakteri yaitu, kavikol yang mempunyai daya membunuh bakteri lima kali lipat dari fenol biasa. ${ }^{11}$ Terdapat tannin dan fenol yang dapat membunuh bakteri dengan cara mendenaturasi protein sel. ${ }^{12}$ Seskuiterpen merupakan kandungan kimia daun sirih yang memliki akitivitas farmakologi seperti antibakteri, antifungi, dan antimalaria. ${ }^{13}$

Habatussaudah atau disebut dengan Jintan hitam (Nigella sativa) digunakan oleh orang Negara Timur Tengah sebagai obat tradisional dalam mengobati penyakit. ${ }^{14}$ Zat utama yang dikandung oleh minyak jintan hitam yang berfungsi sebagai zat antibakteri yaitu, thymohydroquinone, tannin, dan thymquinone. ${ }^{15}$ Thymoquinone 
merupakan bahan aktif dalam minyak atsiri yang terdapat pada jintan hitam yang memiliki aktivitas antibakteri terhadap bakteri gram positif dan menyebabkan gangguan fungsi sel bakteri dengan menghambat sintesa protein. ${ }^{16} \alpha$-pinene memiliki aktivitas antibakteri gram positif dan gram negatif serta memilik efek yang kuat terhadap jamur. ${ }^{17}$

Berdasarkan dari zat yang terkandung, kedua tumbuhan tersebut dapat menghambat pertumbuhan bakteri. Tujuan dari penelitian ini adalah untuk mengetahui perbedaan daya antibakteri ekstrak jintan hitam dan ekstrak daun sirih hijau terhadap pertumbuhan Staphylococcus auerus pada plat gigi tiruan resin akrilik.

\section{MATERIAL DAN METODE}

Jenis penelitian ini merupakan penelitian eksperimental laboratoris yang dilakukan di Laboratorium Makrobiologi Fakultas Kedokteran dan Ilmu Kesehatan Universitas Muhammadiyah Yogyakarta dan Laboratorium Penelitian dan Penguji Terpadu (LPPT) Universitas Gadjah Mada pada bulan September 2018. Sampel yang digunakan pada penelitian ini adalah resin akrilik heat cured sebanyak 27 sampel yang dibagi menjadi 3 kelompok perlakuan, sehingga masing-masing kelompok terdiri atas 9 resin akrilik. Penelitian ini menggunakan metode dilusi atau pengenceran seri dan pelarut metanol $96 \%$. Subjek penelitian yang digunakan adalah Staphylococcus aureus.

Cakram resin akrilik dengan diameter $10 \mathrm{~mm}$ dan ketebalan $2 \mathrm{~mm}$ yang berjumlah 27 buah direndam dalam saliva selama 1 jam untuk membantu perlekatan Staphylococcus aureus. Cakram resin akrilik dimasukan kedalam cawan petri yang berisi suspense Staphylococcus aureus (Gambar 1), kemudian diinkubasi selama 24 jam dengan suhu $37^{\circ} \mathrm{C}$.

Kelompok kontrol I direndam kedalam ekstrak jintan hitam 0,5\%, kelompok kontrol II direndam dengan ekstrak daun sirih dengan konsentrasi 25\%,

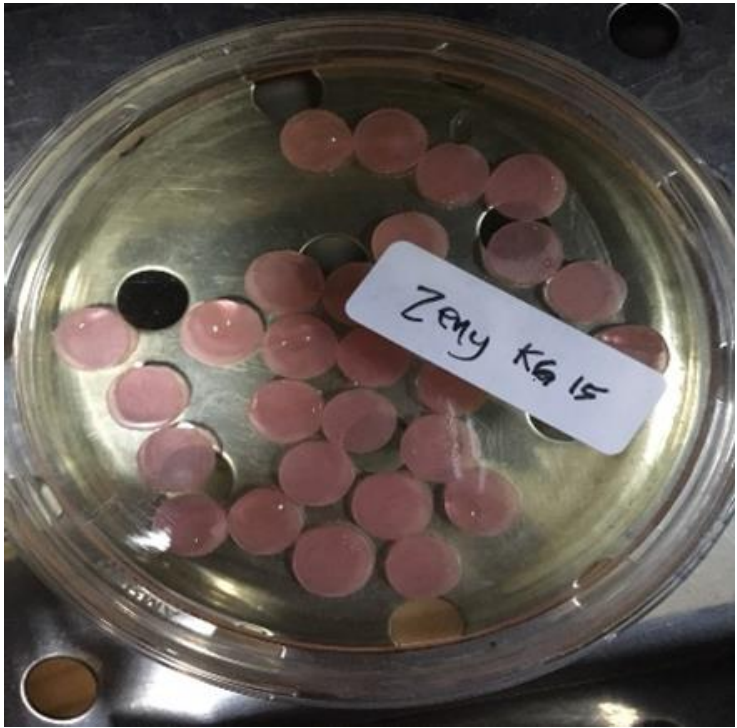

Gambar 1. Perendaman resin akrilik dalam suspense Staphylococcus aures

kelompok III sebagai kontrol negatif menggunakan akuades. Perendaman dilakukan selama 8 jam pada suhu kamar, terlihat pada Gambar 2.

Cakram resin akrilik yang telah direndam kedalam larutan ekstrak jintan hitam, ekstrak daun sirih, dan aquades kemudian dimasukan kedalam tabung reaksi dan masing-masing dikocok dengan vortex mixer selama 1 menit dengan pengenceran seri 10-3. diambil 0,01 ml larutan tes dari pengenceran P3, lalu diteteskan dan diratakan pada cawan petri agar MHA (Gambar 3 dan 4) dan dieramkan dalam incubator selama 24 jam pada suhu $37^{\circ} \mathrm{C}$ kemudian hitung jumlah bakteri. Data yang diperoleh kemudian dianalisis dengan menggunakan MannWhitney test.

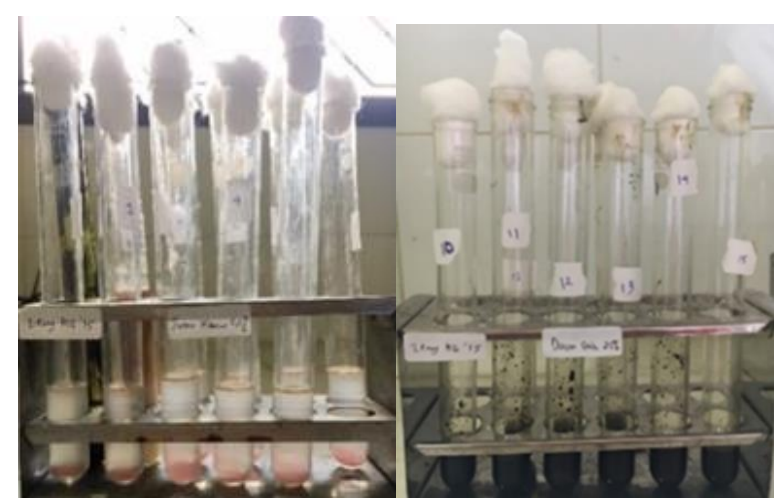

Gambar 2. Perendaman resin akrilik dalam ekstrak daun sirih dan ekstrak jintan hitam. 


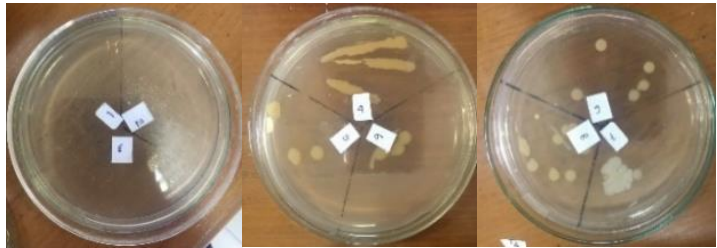

Gambar 3. Bakteri S.aures pada ekstrak jintan hitam

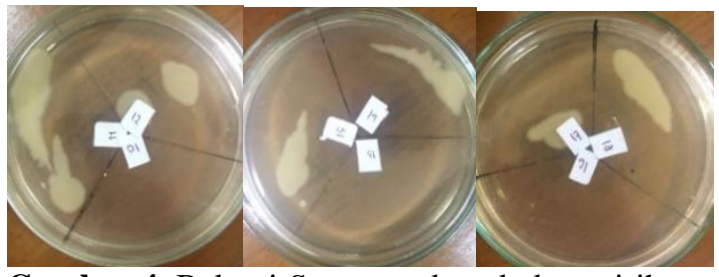

Gambar 4. Bakteri S.aureus ekstrak daun sirih

\section{HASIL}

Pertumbuhan bakteri pada masingmasing kelompok tampak pada Tabel 1. Rerata pertumbuhan bakteri pada kelompok I larutan ekstrak jintan hitam 0,5\% didapatkan yaitu 3,11, kelompok II larutan ekstrak daun sirih $25 \%$ yaitu 1.00 , dan pada kelompok III larutan aquades yaitu 6.00.

Hasil dari tes homogenitas pada seperti pada Tabel 2 menunjukan nilai sig. Levene's test jumlah koloni Staphylococcus aureus pada ekstrak jintan hitam 0,5\%, ekstrak daun sirih $25 \%$, dan aquades yaitu $0,096$ atau lebih dari 0,05 ( $p>0,05)$ yang dinyatakan bahwa data tersebut homogen.

Tabel 1. Jumlah Pertumbuhan Bakteri

\begin{tabular}{lccc}
\hline & \multicolumn{3}{c}{ Jumlah koloni bakteri } \\
& I & II & III \\
\hline Jumlah & 28 & 9 & 54 \\
Rerata & 3,11 & 1,00 & 6,00 \\
\hline
\end{tabular}

Tabel 2. Hasil uji homogenitas Levene's

\begin{tabular}{cccc}
\hline Levene Statistic & Df1 & Df2 & Sig. \\
\hline 2.591 & 2 & 24 & 0,096 \\
\hline
\end{tabular}

Tabel 3. Hasil uji peringkat rata-rata dan perbedaan signifikan Mann Whitney test

\begin{tabular}{lcc}
\hline Jenis Ekstrak & $\begin{array}{c}\text { Mean } \\
\text { Rank }\end{array}$ & $\begin{array}{c}\text { Asymp. Sig. } \\
\text { (2-tailed) }\end{array}$ \\
\hline Jintan hitam 0,5\% & 11,33 &, 135 \\
Daun sirih 25\% & 7,67 & \\
\hline
\end{tabular}

Pengaruh ekstrak jintan hitam dan ekstrak daun sirih pada plat resin akrilik terhadap jumlah Staphylococcus aureus selanjutnya diketahui melalui uji MannWhitney seperti tampak pada Tabel 3. Data Tabel 3 menunjukan peringkat rata-rata tiap kelompok pertumbuhan jumlah koloni bakteri pada ekstrak jintan hitam $0,5 \%$ yaitu 11,33 lebih tinggi dari pada rerata peringkat pertumbuhan jumlah koloni bakteri ekstrak daun sirih $25 \%$ yaitu 7,76. Kemudian, berdasarkan nilai Asymp. Sig. (2- Tailed) atau $p$-value yaitu 0,135 lebih dari 0,05 (p $>0,05$ ) yang berarti H0 diterima artinya tidak terdapat perbedaan yang bermakna antara kelompok ekstrak jintan hitam dengan kelompok ekstrak daun sirih sebagai daya antibakteri terhadap Staphyloccocus aureus pada plat gigi tiruan resin akrilik.

\section{PEMBAHASAN}

Perbedaan angka rata-rata pertumbuhan koloni bakteri pada kelompok ekstrak jintan hitam 0,5\% yaitu 3,11 dan ekstrak daun sirih $25 \%$ yaitu 1,00 . Hal yang mempengaruhi perbedaan angka rata-rata pada penelitian ini salah satunya adalah konsentrasi yang diberikan dalam menghambat pertumbuhan bakteri. Penelitian sebelumnya mengungkapkan bahwa semakin tinggi konsentrasi esktrak yang diberikan menyebabkan kandungan senyawa aktif dalam menghambat pertumbuhan mikroba semakin besar. ${ }^{18}$ Berdasarkan penjelasan tersebut, konsentrasi pada daun sirih lebih besar dibandingkan konsentrasi jintan hitam, sehingga kemampuan daun sirih dalam menghambat Staphyloccocus aureus lebih banyak.

Perlekatan bakteri pada permukaan gigi tiruan akrilik juga dapat disebabkan karena porositas dari akrilik dan permukaan kasar yang pada gigi tiruan. Permukaan yang kasar tersebut memudahkan mikroorganisme untuk berkembang biak dan retensi organisme. Bagian yang paling banyak terkontaminasi, pada daerah posterior gigi tiruan daripada daerah anterior dan bagian dalam gigi tiruan lebih 
banyak terkontaminasi dibandingkan gigi tiruan bagian luar. ${ }^{19}$

Faktor lain yang mempengaruhi penelitian ini yaitu, suhu dan iklim tempat tanaman berasal. Faktor iklim yang dapat mempengaruhi laju pertumbuhan dan proses metabolisme tanaman salah satunya yaitu suhu udara. ${ }^{20}$ Jintan hitam berasal dari daerah yang beriklim subtropis yang memiliki suhu udara yang rendah (di bawah $20^{\circ} \mathrm{C}$ ), tumbuh di dataran tinggi dengan lingkungan tanah basa dan curah hujan rendah. Sedangkan Indonesia beriklim tropis yang mempunyai suhu udara, curah hujan, dan kelembapan yang lebih tinggi, serta tingkat keasaman tanah yang rendah. ${ }^{21}$ Kondisi tersebut menyebabkan jintan hitam di Indonesia tidak dapat tumbuh dengan baik dan kandungan zat aktif pada jintan hitam pun tidak optimal. Hal ini mempengaruhi kualitas dari jintan hitam tersebut sehingga berpengaruh terhadap kemampuan jintan hitam dalam menghambat pertumbuhan bakteri. Sebaliknya, tanaman sirih dapat tumbuh pada daerah iklim tropis dengan ketinggian 100-300 meter diatas permukaan laut, dapat tumbuh di berbagai jenis tanah, terutama ditanah yang mengadung bahan organik, cukup air, dan mendapatkan cahaya matahari penuh. ${ }^{10}$ Sehingga, pertumbuhan daun sirih dapat hidup dengan baik di Indonesia dan kandungan zat aktifnya dalam menghambat pertumbuhan bakteri pun optimal.

Minyak atsiri yang terdapat dalam kandungan daun sirih tersebut mampu melawan beberapa bakteri gram positif dan bakteri gram negatif yang melekat pada plat gigi tiruan resin akrilik. Kandungan kimia yang terdapat daun sirih yang paling dominan yaitu kavikol. ${ }^{13}$ Kavikol memiliki sifat daya antibakteri lima kali lipat dari fenol biasa sehingga dapat menghambat pertumbuhan bakteri dari plat resin akrilik. Flavonoid yang terkandung dalam daun sirih berfungsi sebagai bahan antimikroba dengan membentuk ikatan komplek dengan dinding sel dan merusak membran. ${ }^{22}$ Pada penelitian ini kandungan kimia dalam sirih dapat mengahambat pertumbuhan bakteri dengan cara merusak membran sel dengan cara berikatan dengan dinding sel bakteri. Eugenol pada daun sirih dapat merusak lapisan membran bakteri karena terganggunya rantai asam lemak dari bakteri sehingga terjadi peningkatan permeabilitas membran sel kemudian sel bakteri rusak dan mati. ${ }^{23}$

Terdapat zat thymohydroquinone, tannin, dan thymquinone yang merupakan zat utama yang terkandung dalam minyak atsiri jintan hitam yang berfungsi sebagai zat antimikroba. Thymquinone dan thymohydroquinone berfungsi sebagai inaktivasi protein pada bakteri karena zat tersebut dapat membentuk kompleks yang irreversibel dengan asam amino nukleofilik pada protein bakteri. ${ }^{15} \alpha$-pinene memiliki aktivitas antibakteri gram positif dan gram negatif serta memilik efek yang kuat terhadapa jamur. Mekanisme kerja $\alpha$ pinene sebagai antibakteri adalah dengan menyebabkan efek toksik pada struktur dan fungsi membran. ${ }^{17}$

Pada penelitian ini adanya kandungan suatu zat yang sama pada daun sirih dan jintan hitam yang dapat menganggu membran sel dengan cara menghambat kerja enzim ekstraseluler sehingga dapat menghambat pertumbuhan sel bakteri. Tanin yang terkandung dalam jintan hitam mempunyai sifat pengelat berefek spasmolitik yang dapat mengerutkan dinding sel bakteri atau membran sel sehingga permeabilitas selnya terganggu. Tannin juga mempunyai daya anti bakteri dengan cara mempresipitasikan protein, karena diduga tanin mempunyai efek yang sama dengan senyawa fenolik. ${ }^{5}$

\section{KESIMPULAN}

Berdasarkan hasil penelitian yang telah dilakukan maka dapat disimpulkan, tidak terdapat perbedaan yang bermakna antara ekstrak jintan hitam dan ekstrak daun sirih dalam menghambat pertumbuhan 
Staphylococcus aureus pada plat gigi tiruan.

\section{DAFTAR PUSTAKA}

1. Agtini, M. D. (2010). Persentase pengguna protesa di Indonesia. Media penelitian dan pengembangan kesehatan, 2010; 20(2): 50-58.

2. Noort, R.V., Introduction To Dental Material. 3rd Ed. Philadelphia, USA: Elsevier, 2007.

3. Anusavice, K.J., Philips ; Buku Ajar Ilmu Bahan Kedokteran Gigi. 10th Ed. Translated By L. Juwono. Jakarta: EGC, 2003.

4. Audira, I.A., Widyastuti, N.H. \& Sari, F.N.M., Pengaruh Perendaman Plat Resin Akrilik Dalam Larutan Ekstrak Daun Pandan (Pandanus Amaryllifolius Roxb.) Terhadap Pertumbuhan Jamur Candida Albicans. Skripsi tidak diterbitkan. Solo: Universitas Muhammadiyah Surakarta, 2015.

5. Baena-Monroy, T., MorenoMaldonado, V., Franco-Martinez, F., Aldape-Barrios, B., Quindos, G., \& Sánchez-Vargas, L. O. (2005). Candida albicans, Staphylococcus aureus and Streptococcus mutans colonization in patients wearing dental prosthesis. Med Oral Patol Oral Cir Bucal, 2005; 10(Suppl 1): E27-E39.

6. Dharmautama, M., Edy M \& Sardi, M., Pertumbuhan Bakteri Plak Dan Candida Albicans Pada Basis Gigitiruan Lepasan Akrilik Setelah Perendaman Dalam Infusa Bunga Rosella. Laporan penelitian. Makassar: Bagian Protodonsia Fakultas Kedokteran Gigi Universitas Hasanuddin, 2014.

7. Smith, A. J., Robertson, D., Tang, M. K., Jackson, M. S., MacKenzie, D., \& Bagg, J. Staphylococcus aureus in the oral cavity: a three-year retrospective analysis of clinical laboratory data. $\mathrm{Br}$ Dent J, 2003; 195(12): 701-703.
8. Garg R. Denture Hygiene, Different Strategies. Webmed Central Dentistry 2010; 1(10): WMC00932.

9. Oussama, \& Ahmad, H., Materials And Methods For Cleaning Dentures- A Review. Int. J. Clin. Dent., 2014; 6(2):19-22.

10. Moeljanto, R.D. \& Mulyono, Khasiat \& Manfaat Daun Sirih: Obat Mujarab Dari Masa Ke Semasa. Jilid I. Jakarta: Agromedia Pustaka, 2003.

11. Pambudi, R. R., Sulistyorini, R., \& Mayasari, L. O. Perbedaan Perendaman Plat Resin Akrilik Pada Tablet Pembersih Gigi Tiruan Effervescent dan Air Rebusan Daun Sirih Terhadap Penurunan Jumlah Koloni Jamur Candida albicans. In Prosiding Seminar Nasional \& Internasional, 2017; 1(1): 319-322.

12. Block, S.S., Disinfection, Sterilization, And Preverstion. 5th Ed. Philadelphia: Lippincott Williams and Wilkins, 2001.

13. Alfizia, K. Z., Kornialia, K., \& Utami, S. P. Pengaruh Berkumur dengan Seduhan Daun Sirih Merah terhadap Nilai Plak pada Pemakai Piranti Ortodonti Cekat. B-Dent: Jurnal Kedokteran Gigi Universitas Baiturrahmah, 2016; 3(1): 23-30.

14. Yulianti, S. \& Junaedi, E., Sembuhkan Penyakit Dengan Habbatussaudah. Jilid I. Jakarta: Agromedia Pustaka, 2006.

15. Stern, J.L., Hagerman, A.E., Steinberg, P.D. et al. Phlorotannin-protein interactions. J Chem Ecol, 1996; 22(10): 1877-1899.

16. Supriyana, S., Aryati, E., Sadimin, S., \& Utami, W. J. D. Kemampuan Obat Kumur Ekstrak Jinten Hitam Sediaan Kantong Celup terhadap Monosit dan Neutrofil pada Adhesi Streptococcus Mutan. LINK, 2019; 15(2): 36-41.

17. Zhang, X., Lambe, A. T., Upshur, M. A., Brooks, W. A., Gray Bé, A., Thomson, R. J., et al. Highly oxygenated multifunctional compounds in $\alpha$-pinene secondary 
organic aerosol. Environ Sci Technol, 2017; 51(11): 5932-5940.

18. Puteri, T., \& Milanda, T. Uji Daya Hambat Ekstrak Daun Lidah Buaya (Aloe vera L.) Terhadap Bakteri Escherichia coli dan Staphylococcus aureus. Farmaka, 2016; 14(2): 9-17.

19. Salim, S. Gigi Tiruan Jembatan: Fixed Dental Prosthesis. Surabaya: Airlangga University Press, 2017.

20. Kepel, B. J., \& Bodhi, W. Pengaruh pH dan Suhu terhadap Aktivitas Pereduksi Merkuri Bakteri Resisten Merkuri Tinggi Bacillus cereus yang Diisolasi dari Urin Pasien dengan Amalgam Gigi. e-GiGi, 2020; 8(1): 15-21.
21. Aziz, S. A., Kurniawati, A., \& Faridah, D. N. Pertumbuhan dan Produksi Habbatussauda (Nigella sativa L.) di Tiga Ketinggian di Indonesia. J Agron Indones., 2017; 45(3): 323-330.

22. Dewi, R., Febriani, A., \& Wenas, D. M. Uji Aktivitas Antimikroba Ekstrak Metanol Daun Sirih (Piper betle L.) Terhadap Pertumbuhan Bakteri Propionibacterium acnes dan Khamir Malassezia furfur. Sainstech Farma, 2019; 12(1): 32-38.

23. Rahmah, N., \& KN, A. R. Uji fungistatik ekstrak daun sirih (Piper betle L.) terhadap Candida albicans. BioScientiae, 2018; 7(2): 17-24. 